\title{
MASYARAKAT HUKUM ADAT DAN KONSEP PENGUASAAN NEGARA ATAS EKSPRESI BUDAYA TRADISIONAL DI INDONESIA
}

\author{
Ida Bagus Wira Adi Manuaba, Fakultas Hukum Universitas Udayana, e-mail: \\ wiraa1995@gmail.com \\ Anak Agung Gede Duwira Hadi Santosa, Fakultas Hukum Universitas \\ Udayana, e-mail: agung_santosa@unud.ac.id
}

doi: https://doi.org/10.24843/KS.2020.v08.i12.p01

\begin{abstract}
ABSTRAK
Tujuan dilakukan penelitian ini agar dapat memahami konsep penguasaan Negara sebagai pemegang Hak Cipta atas EBT dalam UU Hak Cipta Tahun 2014 dan untuk mengetahui serta mengevaluasi kedudukan masyarakat hukum adat sebagai pengemban EBT saat ini agar dapat dilindugi dengan tepat dengan ketentuan hukum yang sui generis. Dalam penelitian ini menggunakan metode penelitian hukum normatif dengan pendekatan penelitian yaitu pendekatan perundang-undangan dan pendekatan analisis konsep hukum. Serta dengan teknik analisis data yang digunakan yaitu teknik analisis deskriptif kualitatif. Hasil penelitian ini yaitu bahwa sampai saat ini konsep penguasaan Negara yang menjadi pemegang Hak Cipta atas EBT sebagaimana ketentuan yang diatur pada Pasal 38 ayat (1) UUHC belum tepat diterapkan. Hal ini didasarkan pada beberapa pendapat salah satunya yaitu adanya perbedaan konsep perlindungan karya cipta individual pada umumnya dengan konsep perlindungan EBT yang termasuk karya cipta komunal dan diwariskan secara turun temurun. Dalam permasalahn terkait kedudukan masyarakat hukum adat yang sampai sekarang belum jelas disebutkan dan diatur dalam UUHC, penting untuk kedepannya diatur secara tersendiri ketentuan peraturan perundang-undangannya dan wajib menyebutkan serta mengatur kedudukan masyarakat hukum adat beserta hak-haknya atas EBT yang telah diemban dan dilestarikannya selama ini. Mengingat peran vital masyarakat hukum adat yang telah berperan positif melestarikan tradisinya dengan pengaturan khusus yang memberikan pemegang Hak Cipta ata EBT kepada masyarakat adatnya.
\end{abstract}

Kata Kunci: Ekspresi Budaya Tradisional, Penguasaan Negara, Masyarakat Hukum Adat

\begin{abstract}
The purpose of this research is to understand the concept of State control as the holder of Copyright over EBT in the Copyright Law of 2014 and to find out and evaluate the position of indigenous peoples as the current EBT bearers so that they can be properly protected by sui generis legal provisions. In this study, using a normative legal research method with a research approach that is a statutory approach and a legal concept analysis approach. And the data analysis technique used is descriptive qualitative analysis techniques. The result of this research is that until now the concept of State control which is the holder of the Copyright on EBT as stipulated in Article 38 paragraph (1) of the UUHC has not been properly applied. This is based on several opinions, one of which is the difference in the concept of protection of individual copyright works in general with the concept of EBT protection, which includes communal copyright works and is passed down from generation to generation. In matters related to the position of the customary law community which until now has not been clearly stated and regulated in the UUHC, it is important for the future to be regulated separately the provisions of the laws and regulations and must mention and regulate the position of the customary law community and their rights over EBT which have been carried and preserved for this. Given the vital role of indigenous peoples who have played a positive role in
\end{abstract}


preserving their traditions with special arrangements that provide Copyright or EBT holders to their customary communities.

Key words: Traditional Cultural Expression, Country Mastery, Indigenous Law Community

\section{Pendahuluan}

\subsection{Latar Belakang}

Julukan Indonesia sebagai museum hidup dunia dikarenakan Indonesia memiliki beragam kekayaan tradisi dan budaya yang dimiliki dan masih lestari hingga saat ini. Keragamanan budaya dan tradisi lahir dari proses hidup masyarakat Indonesia yang bergantung pada kondisi alamnya. Alam dan perkembangan hidup masyarakat Indonesia tidak dapat dilepaskan, hal ini karena kondisi alam mempengaruhi pola hidup masyaraktnya yang kemudian menghasilkan suatu kebudayaan yang beragam. Selain karena kondisi alam, kebudayaan yang lahir juga dihasilkan karena kemampuan intelektualitas masyarakat Indonesia sejak dulu yang sangat kreatif. Suatu budaya dan tradisi lahir karena adanya cipta rasa dan karsa manusia dalam suatu kelompok masyarakat, termasuk yang terjadi di Indonesia. Segala kreativitas itulah yang kemudian menghasilkan budaya dan tradisi sebagai bentuk karya-karya intelektual yang bernilai tinggi di tengah perkembangan dunia saat ini. Keadaan ini menjadi peluang terjadinya tindakan pengakuan oleh pihak yang tidak bertanggung jawab akibat lemahnya perlindungan hukum oleh pemerintah. ${ }^{1}$ Meingingat kekayaan intelektual seperti budaya dan tradisi merupakan sebuah ekspresi budaya tradisional (selanjutnya disebut EBT) di Indonesia sangat banyak sehingga perlu upaya yang ekstra untuk mencegah pengakuan pihak asing dalam hal ini negara yang pernah terjadi pada beberapa kesenian yang di klaim oleh Negara tentangga, Malaysia tahun 2010. Hal ini menandakan bahwa pemerintah itu belum maksimal melakukan upaya perlindungan hukum untuk melindungi kekayaan budaya yang tertuang dalam berbagai bentuk ekspresi budaya tradisional masyarakat.

Pasca kejadian tersebut, pemerintah akhirnya melakukan evaluasi terhadap beberapa aturan hukum yang mengatur hal-hal di bidang kekayaan intelektual termasuk ketentuan yang mengatur tentang Hak Cipta. Hal ini dikarenakan dalam UU Hak Cipta pada prinsipnya aturan mengenai perlindungan hukum atas karya seni dan sastra sebagai objek perlindungannya. Akan tetapi, karya seni dan sastra yang merupakan warisan turun temurun pada awalnya belum mendapatkan jaminan perlindungan hukum yang tegas dan pasti di dalam UU Hak Cipta sebagai bentuk EBT. Bahwa EBT merupakan karya-karya yang tidak diketahui Penciptanya dan telah diwariskan secara turun temurun dalam suatu masyarakat pengembannya yaitu masyarakat adat di suatu daerah. Serta perlindungan hukumnya juga belum mampu mengikuti perkembangan zaman, sehingga atas dasar tersebut dilakukan pengubahan beberapa aturan hukum yang mengatur tentang Hak Cipta dengan dibentuknya Undang-Undang Nomor 28 Tahun 2014 tentang Hak Cipta (selanjutnya disebut $\mathrm{UUHC})^{2}$

1 Rachmanullah, Danu, Lindati Dwiatin, and Kasmawati Kasmawati. "Perlindungan Hukum Terhadap Eskpresi Budaya Tradisional Menurut Undang-Undang Nomor 28 Tahun 2014." Pactum Law Journal 1, No.04 (2018): 348-361.

2 Santyaningtyas, Ayu Citra, Rasyikah Md Khalid, and Nur Fadzlun Johan. "Perlindungan Ekspresi Budaya Tradisional di Indonesia: Suatu Penilaian Undang-undang." Jurnal Undangundang dan Masyarakat 2, No.4 (2020): 25-32. 
Walaupun demikian, sistem hukum saat ini yang mengatur tentang perlindungan Hak Cipta ata EBT belum mampu memberikan perlindungan yang memadai. Sebenarnya, syarat utama bagi perlindungan EBT adalah mengetahui harapan-harapan komunitas EBT yang sebenarnya menjadi "tuan"-nya. Juga amat penting meninjau isuisu terkini tentang skema perlindungan yang memadai bagi EBT. Namun demikian, penelitian ini baru sampai tahap awal, yakni mengkaji historisitas dimasukkannya EBT ke dalam ranah hukum Hak Cipta dan makna konsep penguasaan Negara atas EBT selaku pemegang Hak Ciptanya. ${ }^{3}$

Selama kurun waktu 28 tahun, hukum Hak Cipta Indonesia sudah 4 (empat) kali diganti sejak pertama kali diundangkannya UUHC nasional tahun 1982. Keempat undang-undang tersebut mencantumkan EBT sebagai salah satu bidang yang dilindungi oleh hukum hak cipta. Konsep penting dalam UUHC- Hak Moral (HM) dan Hak Ekonomi (HE), sepenuhnya tidak dapat diterapkan untuk EBT, karena EBT tidak dapat ditelusur siapa pencipta awal- sehingga hak moral melekat padanya. Jika konsep hak moral yang merupakan konsep pokok tidak dimiliki dalam EBT, apalagi konsep hak ekonomi-yang merupakan konsep lanjutan konsekuensi dari hak moral tersebut. Selain itu, negara diberi otoritas oleh undang-undang sebagai pemegang Hak Cipta. Otoritas memegang hak cipta atas EBT menjadi problem di tingkat teoretis dan praktis. Pada tingkat dan tataran teoretis, EBT tidak tepat dikategorikan sebagai rezim hukum Hak Cipta hal ini dikarenakan konsep dasarnya yang berbeda antara karya yang mendapatkan perlindungan Hak Cipta dan Karya EBT itu sendiri. Lebih lanjut, dalam tataran atau tingkatan praktis, peran negara sebagai pemegang hak cipta masih perlu diperjelas pelaksanaan konkretnya dan adanya ketidakjelasan kedudukan masyarakat adat sebagai pengemban EBT yang sudah seharunya mendapatkan prioritas manfaat dan kejelasan kedudukannya dalam system hukum yang menjadi dasar perlindungannya. Berdasarkan hal tersebut dalam penelitian ini diangkat judul "Masyarakat Hukum Adat dan Konsep Penguasaan Negara Atas Ekspresi Budaya Tradisional di Indonesia."

Artikel ilmiah ini dibuat dengan judul Masyarakat Hukum Adat dan Konsep Penguasaan Negara Atas Ekspresi Budaya Tradisional di Indonesia berdasarkan keinginan untuk memahami konsep perlindungan hukum EBT yang tepat dan sesuai dengan kondisi sosial masyatakat Indonesia khususnya terkait konsep penguasaan negara selaku pemegang Hak Cipta atas EBT dan kedudukan masyarakat hukum adat sebagai pengemban EBT selama ini dalam perspektif hukum Hak Cipta yang berlaku saat ini yang belum terdapat publikasi ilmiah yang sama atau memiliki persamaan pada prinsipnya dengan permasalahan yang dikaji pada artikel ilmiah ini baik dalam jurnal nasional maupun internasional.

\subsection{Permasalahan}

Sesuai dengan penjelesan latar belakang masalah, dapat kemudian dirumuskan permasalahan yaitu sebagai berikut:

1. Bagaimana konsep penguasaan Negara ditinjau dari kedudukan Negara sebagai pemegang Hak Cipta atas EBT dalam UU Hak Cipta?

2. Bagaimana kedudukan masyarakat hukum adat sebagai pengemban EBT dalam terkait perlindungannya dalam rezim hukum Hak Cipta?

3 Bustani, Simona. "Urgensi Pengaturan ekspresi Budaya (Folklore) Masyarakat Adat." Jurnal Hukum PRIORIS 2, No.4 (2016): 246-255. 


\subsection{Tujuan Penelitian}

Tujuan penelitian ini adalah untuk memahami konsep penguasaan Negara ditinjau dari kedudukan Negara sebagai pemegang Hak Cipta atas EBT dalam UU Hak Cipta yang berlaku saat ini dan untuk mengetahui dan mengevaluasi kedudukan masyarakat hukum adat sebagai pengemban EBT dalam terkait perlindungannya dalam rezim hukum Hak Cipta kedepannya.

\section{Metode Penelitian}

Pada penyusunan artikel ilmiah ini yang merujuk pada hasil penelitian, digunakan metode penelitian yang merupakan suatu hal yang mendasar pada hakikatnya bermakna memberikan pedoman dalam mempelajari, menganalisis, dan memahami hukum yang dimaksud. Dengan kata lain bahwa suatu ilmu dan pengetahuan didapatkan melalui penelitian dengan metode ilmiahnya. Metode penelitian yang digunakan dalam penelitian ini yaitu metode penelitian hukum dengan jenis penelitian hukum yaitu penelitian hukum yaitu jenis penelitian yang membahas dan menganalisis dalam tataran norma, asas dan doktrin hukum. ${ }^{4}$ Adapun jenis pendekatan yang digunakan untuk menunjang penelitian hukum normative yaitu pendekatan pendekatan perundang-undangan dan analisis konsep hukum. Untuk kemudian semua bahan hukum yang telah dikumpulkan kemudian dianalisa dengan teknik analisis deskriptif kualitatif untuk disusun sedemikian rupa dengan sistematika yang sesuai dan baik.

\section{Hasil dan Pembahasan}

3.1. Konsep Penguasaan Negara Ditinjau Dari Kedudukan Negara Sebagai Pemegang Hak Cipta Atas EBT Dalam UU Hak Cipta

Adanya jaminan perlindungan hukum atas karya-karya EBT dalam rezim Hak Cipta memberikan angin segar bagi pelestarian karya intelektual dari masyarakat adat di seluruh Indonesia. Perlu disadari bahwa suatu karya intelektual manusia yang bernilai ekonomis yaitu karya seni dan budaya sebagai hasil kreativitas manusia dalam melahirkan berbagai karya intelektualitasnya yang bermutu tinggi tidaklah dilahirkan begitu saja. Sehinga karya seni dan budaya patut mendapat perlindungan yang pada akhirnya dapat meningkatkan taraf kesejateraan, tidak hanya untuk masyarakat adat dimana seni itu tumbuh dan berkembang, namun juga untuk bangsa dan negara Indonesia. Hasil karya intelektual itu lahir dari pengolahan dan proses dari cipta, karsa dan daya kreativitas manusia yang sedemikian mendalam dan bernilai ekonomis tinggi sudah selayaknya diberikan perlindungan hukum secara kolektif untuk mendapatkan hak ekslusif atas karya yang dilestarikan oleh masyarakat adatnya sampai saat ini. ${ }^{5}$

Bahwa dalam perspektif Hak Cipta berdasarkan UUHC mengenai EBT telah diatur di dalam Pasal 38 ayat (1) UUHC yang mengatur bahwa Hak Cipta atas ekspresi

4 Muhammad, Abdulkadir. Hukum dan Penelitian Hukum. (PT.Citra Aditya Bakti, Bandung, 2014): 52.

5 Sandimas, Putu, and Anak Agung Sri Indrawati. "PERLINDUNGAN HUKUM ATAS KARYA TARI ABUANG DI DESA TENGANAN PEGRINGSINGAN SEBAGAI SATU BENTUK EKSPRESI BUDAYA TRADISIONAL DALAM PERSPEKTIF HAK CIPTA." Kertha Wicara: Journal Ilmu Hukum 9, no. 6: 1-12. 
budaya tradisional dipegang oleh negara. ${ }^{6}$ Apabila mencermati ketentuan tersebut bahwa Hak Cipta atas EBT ada pada Negara, dalam hal ini pemerintah pusat maupun daerah sebagai representasi Negara menguasai EBT tersebut. ${ }^{7}$ Lebih lanjut, mengenai perlindungan EBT, juga telah diatur dan ditegaskan kembali di dalam Pasal 39 UUHC. ${ }^{8}$ Dalam hal jangka waktu perlindungan EBT yang merupakan salah satu objek dari Hak Cipta yang dilindungi tanpa batas waktu sebagaimana diatur dalam Pasal 60 UUHC. Akan tetapi, amanat ketentuan Pasal 38 ayat (4) UUHC sampai saat ini belum dilaksanakan, padahal telah tegas disebutkan bahwa ketentuan lebih lanjut mengenai penguasaan Negara atas EBT dan kewajiban Negara untuk menginventarisasi di ataur dalam Peraturan Pemerintah dan sampai saat ini belum juga dilaksanakan oleh pemerintah selaku pelaksana pemerintahan. Hal ini kemudian menimbulkan problematika hukum yaitu terjadinya berupa ketidakpastian hukum/legal uncertainty dalam praktiknya. Terlebih lagi dengan Negara yang justru memegang peran sebagai pemegang Hak Cipta dari EBT padahal kenyataannya masyarakat hukum adatlah yang melestarikan serta menjaga keberadaan dari EBT tersebut. Tanpa adanya masyarakat hukum adat yang tetap menjalankan budaya yang telah ada secara turun temurun tersebut tentunya budaya tersebut akan mudah tergerus perkembangan zaman.

Tentunya juga jika negara yang bertindak sebagai pemegang Hak Cipta atas EBT, maka secara konsepsi rezim hukum Hak Cipta yang memiliki hak eksklusif atas EBT adalah Negara bukan masyarakat hukum adat yang selama ini mewarisi dan melestarikannya. Justru hak ekslusif tersebut didapatkan oleh Negara dalam hal ini pemerintah, bukan masyarakat hukum adat. Meskipun pada tataran konsepsinya, Negara menguasai EBT semata-mata untuk kepentingan masyarakat hukum adat pengembannya dan rakyat pada umumnya sebagaimana amanat konstitusi. Akan tetapi, perlu diingat bahwa masyarakat hukum adat dalam entitasnya sebagai kesatuan masyarakat hukum adat diakui sebagai subjek hukum dan memiliki hak konstitusional yang dijamin Pasal 18 B ayat (2) UUD NRI Tahun 1945. Telepas dari kenyataan bahwa Negara memiliki peran yang penting dalam perlindungan dari EBT tersebut, tetapi masyarakat hukum adat lah yang membuat budaya tersebut tetap ada dan terjaga, karena masyarakat hukum adatlah pengemban serta pelaku yang meneruskan budaya tersebut, dan tentunya tanpa adanya masyarakat hukum adat tersebut budaya tersebut akan hilang. Maka seharusnya eksklusifitas dari hak cipta tersebut dipegang oleh masyarakat hukum adat itu sendiri sebagaimana konsep yang terdapat dalam Pasal 1 angka 1 UUHC, karena masyarakat hukum adat juga merupakan subyek hukum.

Apalagi banyak pendapat yang menyatakan bahwa pengaturan EBT dalam UUHC tidak tepat karena adanya perbedaan prinsip yang mendasar antara konsep EBT dan konsep Hak Cipta. Selain itu, tidak dijaminnya hak masyrakat adat secara pasti

6 Mustika, I. Made AD, and Ni Ketut Supasti Dharmawan. "Prospek Perlindungan Hukum Ekspresi Budaya Tradisional Dalam Perspektif Hak Cipta." Kertha Semaya: Journal Ilmu Hukum 7, No. 3 (2019): 1-15.

7 Asri, Dyah Permata Budi. "Implementasi Pasal 38 ayat (1) Undang-Undang Nomor 28 Tahun 2014 terhadap Ekspresi Budaya Tradisional di Kabupaten Sleman." Jurnal Hukum Ius Quia Iustum 23, No.4 (2016): 612-632.

8 Nugroho, Sigit. "Pengelolaan Ekspresi Budaya Tradisional (Ebt) Di Daerah Pasca UndangUndang Nomor 28 Tahun 2014 Tentang Hak Cipta: (Perpektif Hukum Administrasi Negara)." Society 5, No.1 (2017): 87-98. 
sebagai pengemban EBT atas Hak Moral maupun Hak Ekonomi yang timbul dari adanya Hak Ekslusif dalam Hak Cipta. ${ }^{9}$ Oleh karena itu, kedudukan negara sebagai pemegang Hak Cipta atas EBT tanpa adanya pengaturan lebih lanjut sejauh mana penguasaan negara dan tidak diaturnya hak-hak masyarakat adat pengemban EBT dalam UUHC juga menimbulkan problematika hukum yang diperlu dikaji kembali apakah EBT tetap dalam rezim Hak Cipta dan penguasaannya ada pada Negara ataukah EBT diatur secara khusus dalam peraturan perundang-undangan terpisah dari UUHC dengan memberikan penguasaan EBT kepada masyarakat adatnya sebagai pengemban atas EBT yang telah diwariskan secara turun temurun. ${ }^{10}$

Bahwa pada prinsipnya konsep penguasaan Negara atas EBT belum sesuai dengan apa yang dikehendaki masyarakat hukum adat sampai saat ini. Bahwa apabila dipahami dengan komprehensif bahwa sejatinya masyarakat hukum adatlah yang sejatinya memahami dan mengerti bagaimana sejarah dan hal-hal prinsipil dari suatu EBT yang telah mereka warisi dari leluhurnya sebagai suatu warisan komunal yatu warisan bersama dan dimiliki secara komulatif oleh mereka dengan segala kewajiban dan manfaat yang seharusnya didapatkan. Maka dari itu, muncul gagasan dan pendapat bahwa EBT sebagai sesuatu yang terbuka dan menjadi milik umum atau public domein khusus bagi masyarakat hukum adat selaku pengembannya. Sehingga konsep penguasaan Negara tanpa memperjelas status hukum dan kedudukan hukum masyarakat hukum adat menjadi suatu konsep yang merugikan masyarakat hukum adat. ${ }^{11}$ Kerugian tersebut tampak ketika suatu EBT tersebut digunakan oleh pihak ketiga untuk kepentingan komersialisasi tentunya keuntungan nya didapatkan oleh negara dan mayarakat hukum adat itu sendiri tidak mendapatkan apa-apa. Inilah kemudian yang menjadi polemik ketika masyarakat hukum adat itu yang mengemban dan melestarikan warisan budaya tersebut secara terus-menerus, namun justru negaralah yang mendapatkan keuntungan secara ekonomis dari penggunaan warisan budaya tersebut.

Oleh karena itu, konsep penguasaan Negara atas EBT selaku pemegang Hak Cipta atas EBT sebagaimana ketentuan yang berlaku saat ini belum tepat diterapkan karena masih adanya perbedaan konsep perlindungan karya Cipta pada umumnya dengan konsep perlindungan EBT yang semestinya yang akhirnya mengurangi manfaat yang harusnya didapatkan masyarakat hukum adat. Sehingga merugikan masyarakat hukum adat sebagai pengemban EBT tersebut selama ini. maka penting untuk mengubah konsep tersebut dan memberikan perlindungan EBT yang bersumber dari adanya masyarakat hukum adat dengan perlindungan sui generis setidak-tidaknya karena tiga alasan, yaitu: (1) pentingnya dilindungi hak masyarakat hukum adat, (2) adanya peluang keuntungan yang ekonomis dengan memanfaatkan EBT tersebut, dan (3) menunjukkan keadilan dalam perkembangan sistem perdagangan dunia saat ini. ${ }^{12}$

\subsection{Kedudukan Masyarakat Hukum Adat Sebagai Pengemban EBT Dalam Terkait Perlindungannya Dalam Rezim Hukum Hak Cipta}

9 Dumpapa, Regina. "Kajian Yuridis Terhadap Pengetahuan Dan Ekspresi Budaya Tradisional Dalam Sistem Hak Atas Kekayaan Intelektual." LEX PRIVATUM 6, No.7 (2019): 134-147.

10 Mustika, I. Made AD, and Ni Ketut Supasti Dharmawan, loc.it

11 Ibid.

12 Sukihana, Ida Ayu, and I. Gede Agus Kurniawan. "Karya Cipta Ekspresi Budaya Tradisional: Studi Empiris Perlindungan Tari Tradisional Bali di Kabupaten Bangli." Jurnal Magister Hukum Udayana (Udayana Master Law Journal) 7, No.1 (2018): 51-62. 
Masyarakat hukum adat merupakan masyarakat yang kuat dalam memegang teguh budaya, adat istiadat, kepercayaan yang diwariskan secara turun temurun dari generasi ke generasi sejak zaman dahulu. Guna memenuhi kebutuhan hidup, masyarakat tersebut sangat tergnatung terhadap sumber daya alam. Hal ini mendorong musik bamboo, serta tari-tarian sebagai miliknya. Pemanfaatan hal serupa juga dialamai oleh Negara-negara sedang berkembang pemiliki EBT seperti India, Peru, Brasil dan beberapa Negara Afrika. Oleh karena itu, EBT penting untuk mendapatkan perlindungan yang mampu mengakomodir kepentingan, manfaat dan hak masyarakat hukum adat selaku pengemban EBT tersebut selama ini. ${ }^{13}$

Kebanyakan ekspresi yang dihasilkan oleh masyarakat hukum adat tersebut berkaitan dengan kebutuhan dari masyarakat hukum adat itu sendiri maka masyarakat hukum adat tersebut sama sekali tidak mementingkan keuntungan terkait dengan hasil karya intelektualnya sebagaimana yang dikonsepkan dalam KI serta hak cipta, padahal saat ini karya intelektual mereka tersebut mendatangkan keuntungan ekonomis yang bisa saja bermanfaat untuk pelestarian EBT dalam masyarakat hukum adat tersebut. Uraian tersebut menunjukan bahwa kepemilikan EBT ini dipegang secara turun temurun oleh masyarakat hukum adat tersebut, pemakaian secara turun temurun atau secara bersama-sama inilah yang menunjukkan sifat komunal dari EBT tersebut, sehingga dapat dikatakan bahwa EBT merupakan hak komunal dari masyarakat hukum adat tersebut. Bahwa perlu dipahami, hak komunal yang dimaksud merupakan hak bersifat publik yaitu hak yang dimiliki oleh semua orang dan terdapat didalam kelompok tersebut karena hak komunal pada dasarnya diturunkan turun temurun dan digunakan secara bersama-sama serta dilestarikan secara bersama-sama oleh kelompok tersebut. Kemudian dari sisi tersebut dapat dilihat bahwa hak komunal juga masuk kedalam ranah hukum privat yang berarti hak tesebut dipegang oleh komunitas tersebut sehingga tidak dapat digunakan oleh orang lain di luar komunitas tersebut.

Mengenai perlindungan terhadap EBT sudah terjadi sejak lama, ketika permasalahan EBT mendapatkan perhatian dan menjadi pembahasan secara internasional sejak empat puluh tahun. Pembahasan ini dimulai sejak revisi atas Konvensi Bern tahun 1967 di Stockholmdan di Paris 1971 yang kemudian diadaptasi ke TRIPs Agreement dan Konvensi PBB tentang Keragaman Hayati. ${ }^{14}$ Sehingga, Indonesia sebagai negara berkembang yang juga menjadi anggota TRIPs Agreement harus mampu menyesuaikan sistem hukum kekayaan intelektual yang disesuaikan dengan kondisi Negara mengenai perlindungan atas karya-karya EBT. ${ }^{15}$ Kemudian Indonesia menggabungkan konsep kepemilikan individual sekaligus konsep kepemilikan kolektif sebagaimana yang terdapat dalam konsep perlindungan Hak Cipta dalam UUHC sebagai bagian dari jenis kekayaan intelektual yang perlu dilindungi. ${ }^{16} \mathrm{Hal}$ ini diakui perlindungannya dengan system perlindungan otomatis seketika setelah karya tersebut diwujud nyatakaan sebagai sebuah karya sebagaimana atur pada ketentuan Article 2 paragraph (2) Berne Covention menyatakan: "It shall, however, be a matter for legislation in the countries of the Union to prescribe that works in general or any specific categories of works

13 Sandimas, Putu, and Anak Agung Sri Indrawati, Op.Cit., 1-12.

14 Lutviansori, Alif. Hak Cipta dan Perlindungan Foklor di Indonesia. (Graha Ilmu, Yogyakarta, 2010): 4.

15 Rafianti, Laina, and Qoliqina Zolla Sabrina. "Perlindungan bagi Kustodian Ekspresi Budaya Tradisional Nadran berdasarkan Perspektif Hukum Internasional dan Hukum Hak Kekayaan Intelektual di Indonesia." Padjadjaran Journal of Law 1, No.3 (2014): 132-156.

16 Ibid. 
shall not be protected unless they have been fixed in some material form."17 Ini berarti, bahwa suatu karya intelektual di bidang seni, sastra dan ilmu pengetahuan mendapatkan perlindungan ketika telah diwujudkan secara nyata dan difiksasi sebagai suatu bentuk yang riil.18 Kebijakan ini pun akhirnya mendapatkan kritikan dari beberapa ahli dikarenakan prinsip dasar perlindungan EBT yang bersifat komunal tidak sejalan dengan konsep perlindungan individual dalam rezim Hak Cipta. ${ }^{19}$

Pada tahun 1990, Amerika Serikat mengintroduksi aturan khusus yang hanya memberikan perlindungan Hak Moral secara terbatas bagi karya seni visual atau the Visual Artistic Right Act 1990/VARA. Selebihnya, negara-negara yang mengakui konsepsi hak moral, ternyata memiliki derajat penghargaan yang berbeda-beda. Prancis misalnya, mengakui konsep droit de suit, yang penjabarannya juga ditumbuhkan dari konsep hak moral. ${ }^{20}$ Terlebih lai, permasalahan perlindungan EBT melalui hukum Hak Cipta juga sebenarnya sudah menjadi permasalahan yang sering diperdebatkan sejak tahun 1990 hingga saat ini. Misalnya saja didalam pertemuan beberapa negara di Konferensi Stockholm yang membahas tentang revisi Berne Convention dimana delegasi Australia tidak sependapat dengan India masalah penggunaan Berne Convention untuk melindungi EBT, delegasi Australia berpendapat bahwa Berne Convention lebih kepada perlindungan KI individu yang diketahui dengan jelas siapa penciptanya sedangkan EBT biasanya dimiliki oleh komunitas secara kolektif. ${ }^{21}$ Kemudian menurut Torsen perlindungan EBT melalui hukum hak cipta juga kurang tepat karena sulitnya mengakomodasi EBT kedalam konsep perlindungan hak cipta dalam hal originalitas, kreativitas dan bentuk yang khas. Namun, menurutnya hukum hak cipta dapat menjadi opsi perlindungan bagi EBT apabila masyarakat hukum adat memberikan izin kepada individu yang ada didalam komunitasnya untuk membuat suatu karya baru berdasarkan pada EBT.

Maka, EBT harus dilestarikan masyarakat pengembannya agar tetap mampu diwariskan kepada generasi berikutnya sebagai warisan yang adiluhung karena nilainilai kehidupan dan moral yang terkandung di dalamnya agar tetap tegak sampai berakhirnya peradaban masyarakatnya. ${ }^{22}$ Dengan demikian, masyarakat adat diberikan status sebagai Pemegang Hak Cipta atas EBT yang telah diwariskan secara turun temurun dan tetap dilestarikan kepada generasi seterusnya. ${ }^{23}$ Sebagaimana yang diatur di Panama melalui sistem hukum sui generis nya yaitu Panama Law dapat menjadi salah satu contoh yang baik bagi perlindungan terhadap EBT, dimana hukum Panama menempatkan masyarakat hukum adat sebagai pemegang dari EBT dan masyarakat

17 Wedhitami, Bayangsari. "Upaya Perlindungan Ekspresi Budaya Tradisional Dengan Pembentukan Peraturan Daerah." LAW REFORM 9, No. 2 (2014): 32-48.

18 Asri, Dyah Permata Budi, loc.it

19 Senewe, Emma Valentina Teresha. "Efektivitas Pengaturan Hukum Hak Cipta Dalam Melindungi Karya Seni Tradisional Daerah." Jurnal LPPM Bidang EkoSosBudKum 2, No.2 (2015): 12-23.

20 Hasima, Rahman. "Perlindungan Hukum Terhadap Ekspresi Budaya Tradisional Masyarakat Adat Tolaki." Literasi Hukum 2, No.1 (2018): 15-27.

21 Agal, Abdolhamed Maoud M Agal, 2016, To What Extent Can Libyan Intellectual Property Laws Protect Tradirional Cultural Ekspressiona From Unauthorised Use?, Thesis The School of Law The Faculty of Professions The University of Adelaide, Australia, h. 14.

22 Asri, Dyah Permata Budi. "Perlindungan Hukum Preventif Terhadap Ekspresi Budaya Tradisional di Daerah Istimewa Yogyakarta Berdasarkan Undang-Undang Nomor 28 Tahun 2014 Tentang Hak Cipta." JIPRO: Journal of Intellectual Property 1, No.1 (2018): 13-23.

23 Ibid. 
hukum adat juga berhak atas pembagian keuntungan apabila EBT tersebut menghasilkan keuntungan ekonomis. ${ }^{24}$ Begitu juga putusan hakim-hakim di Australia yang merupakan negara Common Law terhadap beberapa kasus EBT dapat menjadi contoh yang baik bagi perlindungan terhadap masyarakat hukum adat atas EBT nya, bahwa hukum adat juga harus diakui dan dihormati keberadaannya untuk menjamin keadilan serta kepastian hukum bagi masyarakat hukum adat tersebut. ${ }^{25}$ Lebih lanjut, pentingnya pengaturan secara sui generis terkait perlindungan bagi EBT yang seharunya dikaitkan dengan kedudukan masyarakat hukum adat selaku pengemban EBT selama ini. Oleh karena itu, kedudukan masyarakat hukum adat penting disebutkan dan diatur dalam konsep perlindungan hukum EBT kedepannya. Mengingat peran vital masyarakat hukum adat yang telah berperan positif melestarikan tradisinya dengan pengaturan khusus yang memberikan pemegang Hak Cipta ata EBT kepada masyarakat adatnya.

Untuk itu, perlu diatur mengenai konsep pembagian manfaat dari pemanfaatan EBT kemudian dengan pembagian yang adil. Hal ini berlaku apabila ternyata EBT yang mereka emban menghasilkan keuntungan ekonomis dapat dilakukan melalui sistem Benefit Sharing. Sistem ini merupakan sistem yang diatur secara Internasional pada United Nations Conventions on Biological Diversity (selanjutnya disingkat menjadi UNCBD). Sistem Benefit Sharing ini terdapat didalam ketentuan Pasal 8 huruf $j$ UNCBD menyatakan bahwa setiap negara selama mungkin dan sesuai negara peserta harus menghormati, melestarikan, melindungi baik itu pengetahuan, innovasi serta kebiasaan-kebiasaan atau penerapan sesuau termasuk dari masyarakat asli atau komunitas lokal dan memperomosikan budaya mereka dengan persetujuan serta mengikutsertakan pemegang pengetahuan, inovasi serta kebiasaan-kebiasaan dan mendorong pembagian yang adil dari keuntungan yang didapatkan dari penggunaannya. Ketentuan Pasal 8 huruf j UNCBD tersebut mengakui pentingnya untuk mengakui, menghormati serta memelihara kebiasaaan, pengetahuan serta praktik-praktik yang dihasilkan oleh masyarakat hukum adat. Hal ini juga untuk mengatur penggunaan karya masyarakat hukum adat tersebut haruslah terdapat pembagian keuntungan yang adil dengan masyarakat hukum adat sebagai pemegang karya tersebut. Maka, sistem benefit sharing ini dapat dijadikan salah satu cara menjamin hak-hak dari masyarakat hukum adat sebagai pengemban dari EBT. Sebenarnya pemerintah Indonesia sudah meratifikasi UNCBD melalui UU Nomor 5 Tahun 1994, dan dapat dijadikan dasar peritimbangan untuk menjamin keadilan serta kepastian hukum bagi masyarakat hukum adat atas EBT yang diembannya.

\section{Kesimpulan}

Bahwa konsep penguasaan Negara atas EBT selaku pemegang Hak Cipta atas EBT sebagaimana ketentuan yang diatur pada Pasal 38 ayat (1) UUHC belum tepat diterapkan. Mengingat terdapat perbedaan konsep perlindungan karya Cipta pada umumnya dengan konsep perlindungan EBT yang semestinya penguasaan EBT ada pada masyarakat hukum adat. Mengenai kedudukan masyarakat hukum adat saat ini belum jelas dalam UUHC, sehingga penting untuk kedepannya diatur secara tersendiri mengenai perlindungan hukum EBT dengan menyebutkan dan mengatur hak-hak

24 Sylvana Murni D. Hutabarat, "Perkembangan Dan Perlindungan Pengetahuan Tradisional Dan Ekspresi Budaya Tradisional Ditinjau Dari Perspektif Hak Kekayaan Intelektual," Jurnal Yuridis 2, No. 2 (2015): 202-220.

25 Ibid. 
masyarakat hukum adat atas EBT yang telah diemban dan dilestarikannya selama ini. Mengingat peran vital masyarakat hukum adat yang telah berperan positif melestarikan tradisinya dengan pengaturan khusus yang memberikan pemegang Hak Cipta ata EBT kepada masyarakat adatnya. Adapun saran yang dapat diberikan yaitu menganalisa dan meninjua konsep benefit sharing yang telah diatur Pasal 8 huruf $\mathrm{j}$ UNCBD dan telah diadopsi beberapa Negara seperti Negara Panama dan Australia untuk kemudian diterapkan dalam konsep perlindungan hukum EBT yang sui generis.

\section{DAFTAR PUSTAKA}

Buku:

Lutviansori, Alif. Hak Cipta dan Perlindungan Foklor di Indonesia. (Graha Ilmu, Yogyakarta, 2010).

Muhammad, Abdulkadir. Hukum dan Penelitian Hukum. (PT.Citra Aditya Bakti, Bandung, 2014).

\section{Skripsi/Tesis/Disertasi:}

Agal, Abdolhamed Maoud M Agal, 2016, “To What Extent Can Libyan Intellectual Property Laws Protect Tradirional Cultural Ekspressiona From Unauthorised Use?", Thesis The School of Law The Faculty of Professions The University of Adelaide, Australia.

\section{Jurnal:}

Asri, Dyah Permata Budi. "Implementasi Pasal 38 ayat (1) Undang-Undang Nomor 28 Tahun 2014 terhadap Ekspresi Budaya Tradisional di Kabupaten Sleman." Jurnal Hukum Ius Quia Iustum 23, No.4 (2016).

"Perlindungan Hukum Preventif Terhadap Ekspresi Budaya Tradisional di Daerah Istimewa Yogyakarta Berdasarkan Undang-Undang Nomor 28 Tahun 2014 Tentang Hak Cipta." JIPRO: Journal of Intellectual Property 1, No.1 (2018).

Bustani, Simona. "Urgensi Pengaturan ekspresi Budaya (Folklore) Masyarakat Adat." Jurnal Hukum PRIORIS 2, No.4 (2016).

Dumpapa, Regina. "Kajian Yuridis Terhadap Pengetahuan Dan Ekspresi Budaya Tradisional Dalam Sistem Hak Atas Kekayaan Intelektual." LEX PRIVATUM 6, No.7 (2019).

Hasima, Rahman. "Perlindungan Hukum Terhadap Ekspresi Budaya Tradisional Masyarakat Adat Tolaki." Literasi Hukum 2, No.1 (2018).

Mustika, I. Made AD, and Ni Ketut Supasti Dharmawan. "Prospek Perlindungan Hukum Ekspresi Budaya Tradisional Dalam Perspektif Hak Cipta." Kertha Semaya: Journal Ilmu Hukum 7, No. 3 (2019).

Nugroho, Sigit. "Pengelolaan Ekspresi Budaya Tradisional (Ebt) Di Daerah Pasca Undang-Undang Nomor 28 Tahun 2014 Tentang Hak Cipta:(Perpektif Hukum Administrasi Negara)." Society 5, No.1 (2017).

Rachmanullah, Danu, Lindati Dwiatin, and Kasmawati Kasmawati. "Perlindungan Hukum Terhadap Eskpresi Budaya Tradisional Menurut Undang-Undang Nomor 28 Tahun 2014." Pactum Law Journal 1, No.04 (2018).

Rafianti, Laina, and Qoliqina Zolla Sabrina. "Perlindungan bagi Kustodian Ekspresi Budaya Tradisional Nadran berdasarkan Perspektif Hukum Internasional dan Hukum Hak Kekayaan Intelektual di Indonesia." Padjadjaran Journal of Law 1, No.3 (2014). 
Santyaningtyas, Ayu Citra, Rasyikah Md Khalid, and Nur Fadzlun Johan. "Perlindungan Ekspresi Budaya Tradisional di Indonesia: Suatu Penilaian Undang-undang." Jurnal Undang-undang dan Masyarakat 2, No.4 (2020).

Senewe, Emma Valentina Teresha. "Efektivitas Pengaturan Hukum Hak Cipta Dalam Melindungi Karya Seni Tradisional Daerah." Jurnal LPPM Bidang EkoSosBudKum 2, No.2 (2015).

Sukihana, Ida Ayu, and I. Gede Agus Kurniawan. "Karya Cipta Ekspresi Budaya Tradisional: Studi Empiris Perlindungan Tari Tradisional Bali di Kabupaten Bangli." Jurnal Magister Hukum Udayana (Udayana Master Law Journal) 7, No.1 (2018).

Sylvana Murni D. Hutabarat, "Perkembangan Dan Perlindungan Pengetahuan Tradisional Dan Ekspresi Budaya Tradisional Ditinjau Dari Perspektif Hak Kekayaan Intelektual," Jurnal Yuridis 2, No. 2 (2015).

Wedhitami, Bayangsari. "Upaya Perlindungan Ekspresi Budaya Tradisional Dengan Pembentukan Peraturan Daerah." LAW REFORM 9, No. 2 (2014).

\section{Peraturan Perundang-Undangan}

Undang-Undang Nomor 28 Tahun 2014 tentang Hak Cipta, Lembaran Negara Republik Indonesia Tahun 2014 No. 266, Tambahan Lembaran Negara Republik Indonesia No. 5599)

Undang-Undang Nomor 5 Tahun 1994 Tentang Pengesahan United Nations Convention On Biological Diversity (Konvensi Perserikatan Bangsa-Bangsa Mengenai Keanekaragaman Hayati), Lembaran Negara Republik Indonesia Tahun 1994 Nomor 41, Tambahan Lembaran Negara Republik Indonesia Nomor 3556 